\title{
The Art of (Un)Thinking: When Hyper Productivity Says 'Enough!', Is a Feast
}

\section{Epifania Akosua Amoo-Adare ${ }^{1}$}

Published online: 27 July 2020

(C) Springer Nature Switzerland AG 2020

Keywords Anthropocene - Cognitive justice · Coronavirus · Covid-19 · Critical pedagogy Decoloniality · Feminisms · Neoliberalism • Positionality · Postdisciplinarity · Powerknowledge $\cdot$ Unthinking $\cdot$ Unlearning $\cdot$ Westernized university $\cdot$ Womanism

We are the children of a passionate truth and a truthful passion. We passionately know that reality is not reduced to what exists and that most of what does not exist could and deserves to exist. (Santos 2014: 8)

\section{What's This? I Quit!}

In January 2017, I decided to drop out of a 'westernized university' (see Grosfoguel 2013). I had to leave that never-ending scholarly tale of competition, hyper productivity, over exhaustion, and constant intellectual insecurity. I abandoned the academic track, so I could take the time to deeply reflect on the state of my intellectual affairs. I wanted to decolonize my intellectual existence, in ways that would contribute (in small part) to a long overdue paradigm shift - a radical transformation in the way we think and act in the name of civilizational progress.

In my mind, the academy served as a microcosm of the dire state of neoliberalism across the globe. I found it impossible to continue my unquestioned participation in academic normativity without perpetuating its ideological system of power-knowledge that did absolutely nothing for the many struggles for social and cognitive justice and for eradicating the root causes of the world's numerous 'wicked problems' (Conklin 2005). Through the production of knowledge for a rather linear narrative of growth and civilizational progress, we - as scholars - are significantly implicated in today's world

Epifania Akosua Amoo-Adare

emooadare@gmail.com 
of competitive neoliberalism. And it is this narrow notion of development that is taking us headlong over the edge of our planetary boundary, through extractivism, exploitation, and the mismanagement of the natural environment.

We have pushed so much so that nature has seen fit to strike back. And we are now in the midst of a global pandemic - a self-orchestrated danger - that has put us all on notice. Here in Ghana, the coronavirus pandemic has resulted in the infection of 12,929 people, plus the death of 66 individuals - by the time of writing this article (Ghana Health Service 2020). The virus has greatly slowed down the economy, with adverse effects on agriculture, industry, and services. Consequently, the Ghana government is faced with the insurmountable challenge of enforcing social distancing measures and meeting daily survival needs of numerous individuals working in its informal sector ${ }^{1}$ (Knott 2020), all during a politically charged election year. Accordingly, in March 2020, the country was put on partial lockdown - with the closing of mosques, churches, and schools, as well as its borders. The lockdown has subsequently revealed stark inequalities, especially in the country's education system (Mohamed 2020), including in private schools (Quartey 2020).

\section{(Un)Thinking Science-Beyond the Hierarchy of Cartesian Binaries}

Ghana's coronavirus-challenged existence is no anomaly. Countries around the globe struggle in varying degrees to maintain their economies, keep their citizenry alive, and mediate gaping social inequalities. This global crisis is a significant opportunity to stop and engage in an (un)thinking of the science that makes the world churn. The moment for making this long overdue paradigm shift is right here and right now. I use the word (un)thinking - versus say, rethinking - to stress the need for moving beyond scientific approaches mired in a language of hierarchical Cartesian binaries (Functowicz and Pereira 2015) constructed between minds and bodies, culture and nature, theory and practice, physical and metaphysical, men and women, self and other, and so on - ad infinitum. We need to consider transgressive practices that enable us to gain understandings, albeit partial ones, of contemporary phenomena through knowledge production processes that are not reductionist, exclusionary, elitist, and/or westernized.

I argue for a decolonization of current modes of academic knowledge production, especially in the social and hard sciences. I propose that we seek ways to become reflexive and embodied agents for social and cognitive justice within our institutions, communities, societies, and the world-at-large. This becoming needs to include the development of critical pedagogies (Darder 1992/2009; Freire 1973; McLaren 2001, 2007), which enable us to teach ourselves (and others) how to transgress established knowledge boundaries and move beyond Cartesian thinking. We can do this by inhabiting the ambiguous and frustrating interstices of such false hierarchical binaries, with all of our bodies, minds, hearts, and souls. We need to find ways to link our

\footnotetext{
${ }^{1}$ Approximately $88 \%$ of the Ghanaian population works in the informal sector (Friederich Ebert Stiftung 2020). This is an increase from 80 percentage, as reported nine years ago by Osei-Boateng and Ampratwum (2011), who also state that the sector is characterized by low wages, underemployment, bad working conditions, and uncertain work relationships.
} 
multiple and intersectional selves into our work, leaving nothing by the wayside - not especially the quirky aspects of our identities.

If we are aware that reality is socially constructed and that much of our everyday is about performativity (Butler 1988), then why do we see fit to unquestionably apportion some parts of ourselves (e.g., emotion, artistry, activism, or spirituality) out from 'objective' scientific work? To engage in (un)thinking, we need to think with more than our minds. We need to also think with our hearts, since, after all, heart cells also have memory (Pearsall 1999; Pearsall, Schwartz and Russek 1999). Paul Pearsall (1999: 65) describes the power of the heart, its cellular memory and ability to transmit energy into the human body. He tells us that 'the heart is 5000 times more electromagnetically powerful than the brain,' thus giving us an inkling of the real potential in the idea of 'thinking from the heart.' Unsurprisingly, this is already well known within the indigenous epistemology of the Aymara, a Native American population living in the Andes (Burman 2012).

Additionally, we must consider and experience knowledges that are not only read through the textual but also expressed through the visual, heard through ears, smelt with the nose, tasted by the tongue and the skin, intuited in our bones, foretold in our dreams, and sensed on both physical and metaphysical planes. (Un)thinking, then, is a wallowing, and perhaps for some, even a drowning in changeable seas of knowledge (im)possibilities, which are at times fresh and soothing in their familiarity, but often rough, salty, and terrifying in their chaotic inundations - as they wrench us through many unknown conceptions of existence.

\section{The Art of (Un)Thinking-A Quest for the Reconstitution of Knowledge(s) Otherwise}

This notion of (un)thinking science can be situated within other current scientific debates that recognize the need for renewed intersectional, embodied, and transgressive approaches to knowledge production. Such approaches are necessary because of the complex, dynamic, 'multiplicitous,' and uncertain nature of contemporary phenomena. They are also crucial for the decolonization of the westernized university and its many modes of internationalized knowledge production, associated with the occlusion and/or eradication of other ways of seeing, knowing, sensing, and becoming in and of this world (Asante 2012; Grosfoguel 2013; Mignolo 2009; Ndlovu-Gatsheni 2015). (Un)thinking, ultimately, is also an art form that contributes to the long overdue paradigm shift in knowledge production.

As one example of (un)thinking, I have become entangled in an uncharted exploration of various embodied modes of un-learning, which include my continuous development of critical spatial literacy (Amoo-Adare 2013). ${ }^{2}$ In doing so, I have been formulating, for myself (and potentially others), some kind of embodied womanistfeminist intellectualism (Maparyan 2012) that is not only organic and spiritual but also purposeful, measured, and yet too rhizomatic in its creative and sacred pursuit of

\footnotetext{
2 That is, the critical awareness of historical, geographical, economic, cultural, and political meanings that inform and are informed by the built environment and its constructs (both physical and ideological), so as to enable one's own spatial agency.
} 
learning by/through living without many of the boundaries that matter to (a successful, ibid career-oriented) existence in today's material world. This intellectualism is aimed towards the co-construction of diverse theories and transformations that highlight the diversity of epistemologies, ontologies, cosmologies, and philosophies of life that inhabit our multiverse.

I am still new to this radical practice that began three years ago, with my decision to leave the fast-paced machinations of productive academic life, in order to sit, listen, wait, and see. More importantly, I have taken up key spiritual questions that in fact drive much of scientific and even personal inquiry around the globe: Who am I? What do I want in life? How do I relate (myself and what I want) back to others (Gangaji 2013)? I do so, while recognizing how my economic privilege enables this luxury of self-inquiry. In this way, I have been attempting to inhabit a kind of 'in-between existence'; one which attempts to strike a balance between an artless meandering through subjects I claim to know and the vast unknown. This existence counters the idea of being a knowledgeable expert on any aspect of life in its sacred complexity and dynamism.

Many years before, I engaged in this kind of query, however, through strong identification with my work in higher education in the Global North and international development in the Global South. At that time, any aspect of me that may have been categorized as artistic flair was required to take a back seat within the hierarchical segregation of everyday academic life. Here, I speak of academia's inherent 'disciplinary decadence' (Gordon 2006: 8) that affixes scholars in academic niches, funding cycles, and/or set career pathways, while requiring pain-of-death allegiances - simply because many of these 'disciplines lose sight of themselves as efforts to understand the world and have collapsed into the hubris of asserting themselves as the world'.

This is yet another false splitting of the intellectual, embodied, experiential, and spiritual self, which according to some cultures is seen as a collective made up of millions of cells, microbiomes, memories, and much more than we are yet to fathom. I have found that taking up those disciplinary distinctions undermines my understanding of a true pursuit of knowledge. From my experience of deep inquiry, this pursuit is often a matter of sitting with many uncomfortable and pain-filled days of 'doing nothing' purposefully, 'waiting and seeing,' plus raising questions into a mind quieted through meditation, or other quiet contemplation. Within rhizomatic configurations of knowledge, this approach of 'laissez faire meets some modicum of discipline' leads one into, through, around, and/or beyond various knowledge boundaries that attempt to contain academic, and other equally relevant, ways of knowing, sensing, or being.

I advocate this type of coddiwomple into the in-betweens of diverse knowledges and their modes of production because traveling purposefully towards an unknown destination develops a type of 'border consciousness' (Anzaldua 1987/2012). It also creates a borderland, which is fertile ground for the development of 'threshold theories' (Keating 2013). And it is here also that we find a liminal space of yet-to-be known change and infinite possibility. Finally, it must become a form of knowledge production that is additionally intent on (un)learning in order to re-learn a sociality that is geared towards social and cognitive justice (Santos 2014), plus the reconstitution of 'worlds and knowledges otherwise' (Escobar 2007).

This is a non-dualistic practice in which 'I don't know' takes central place. In its practice, the experiential must also receive greater attention, as we relearn how to listen 
to our bodies keenly. The same applies to our ability to truly listen deeply to others, especially of the flora and fauna variety - since here too lies the teeming question of justice. And in this age of the Anthropocene (Haraway et al. 2015), we can quickly bear the dire consequences of our own stubborn inability to be attentive to nature and its other inhabitants.

\section{Covid-19, when 'Enough,' Is a Feast}

In today's multifaceted, dynamic, ambiguous, and uncertain world, we find that certain linear modes of thought — such as ideas of modernity, progress, and development - are now null and void. It is why Ziauddin Sardar $(2010,2015)$ speaks of these as 'postnormal times,' in which we need to think and act-differently - in non-linear terms. More specifically, Sardar tells us that 'postnormal times' are subject to the $3 \mathrm{Cs}$ of 'chaos, complexity and contradiction,' which not only challenge the very notion of life as we assume it to be but also how we imagine our common futures. And this also includes how we conduct the scientific research that informs it all. It is for reasons such as these that Reil Miller $(2013,2015)$ reminds us of the need 'to use a freer anticipatory approach - the emerging discipline of anticipation - or futures literacy, which can help reduce fear of the unknown' (2013: p. 107). For Miller, this is a more systematic way of using the future to inform the present, through scientific inquiry, rather than the typical focus on predictive science.

Similarly, Sardar and John Sweeney (2016) ask us to make uncertainty central to research, as it is often not catered for in most kinds of analysis in the social sciences. More specifically, they propose a new method for foresight and futures researchers (and practitioners), for which they outline 'The Three Tomorrows of Postnormal Times.' In this, Sardar and Sweeney define the future as being comprised of (1) the surface uncertainty of an 'extended present' that has largely already been colonized; (2) the shallow uncertainty of 'familiar future(s),' which are mediated by existing imaginings of the future; and (3) the deep uncertainty of 'unthought future(s).' In light of this understanding of what constitutes as the future, they argue that only collaborative creativity and ethical imagination can be used as tools to help us construct scenarios for this interactive terrain, which is mediated by pure possibility and many 'unknown unknowns.'

Covid-19 is very much about the abrupt encounter of our 'extended present' with an 'unthought future,' which is dragging us kicking and screaming into many 'unknown unknowns.' Basically, we have crashed into the hard edge of our planetary boundary, through the onslaught of the coronavirus. And we are now faced with it, as a dire consequence of our overexploitation and mismanagement of the natural environment. This is epitomized by the creation of the virus's - still contested-epicenter, a wet market in Wuhan, China (Maron 2020; Morrison 2020). It is also safe to say that our deep exploitation and practice of extractivism is a direct result of a western paradigm that sees a great binary separation between culture and nature, with the latter being at the service (and disposal) of the former. ${ }^{3}$

\footnotetext{
${ }^{3}$ Fortunately, this is not an ideology adhered to by all cultures, thus indicating other more equitable possibilities for relating to the natural environment. Take for example notions such as Pachamama.
} 
Moreover, the coronavirus is clearly a negative effect of global capitalism in its increased flows; that is, the fluid epigenetic entanglements (Lock 2015), or networks, of people, fauna, flora, places, ideas, things, etc. (Appadurai 1999; Urry 2007; Latour 2011). It is also an example of how the flows of capital manifest differentially, often, in uneven spatial development (Massey 1991, 1994). This is something we have come to learn the hard way, through Covid-19, as we witness many go hungry, lose jobs, become homeless, and mostly die as a consequence of stark social inequality and the ineptitude of governance without foresight. This all being found even within the best examples of democracy.

Indeed, Covid-19 is here to remind us that 'Enough' is actually a feast that we have chosen to ignore for far too long. It is why we now also find ourselves in the uproar of many past social struggles (Countryman 2020); struggles that — as Angela Davis (2018) says - do not simply emerge spontaneously but rather come as deeply rooted and connected to several heinous past events, with continued nefarious current effects. And while we human beings reactivate these past contestations over geography and knowledge (Said 1977/1995), through moderate protest and marches, nature instead is more brutal and to the point. It leaves us with no doubt that we cannot continue with business-as-usual. It forces us into deep self-inquiry about who we are, what we want, and how we need to relate that back into (and with) the natural world - especially if we care to live beyond the inevitability of the next global crisis of our making. Ultimately, this harsh reality demands innovative forms of knowledge production about the many dynamic (non)human interaction processes. These can only be barely understood through multiple disciplinary perspectives, ${ }^{4}$ as well as through a critical reflection on the positionality ${ }^{5}$ of every researcher enacting these open-ended processes of inquiry.

\section{References}

Amoo-Adare, E. (2013). Spatial literacy: Contemporary Asante women's place-making. New York: Palgrave Macmillan.

Anzaldua, G. (1987/2012). Borderlands La Frontera: The new mestiza. San Francisco: Aunt Lute.

Appadurai, A. (1999). Disjuncture and difference in the global cultural economy. In S. During (Ed.), The cultural studies reader (pp. 220-230). New York: Routledge. https://doi.org/10.1177 /026327690007002017.

Asante, M. K. (2012). Reconstituting curricula in African universities: In search of an Afro-centric design. In C. Alvares \& S. S. Faruqi (Eds.), Decolonising the university: The emerging quest for non-eurocentric paradigms (pp. 33-47). Kuala Lumpur: Penerbit Universiti Sains Malaysia (USM).

Burman, A. (2012). Places to think with, books to think about: Words, experience and the decolonization of knowledge in the Bolivian Andes. Human Architecture: Journal of the Sociology of Self-Knowledge, 10(1), 101-119.

Butler, J. (1988). Performative acts and gender constitution: An essay in phenomenology and feminist theory. Theatre Journal, 40(4), 519-531. https://doi.org/10.2307/3207893.

\footnotetext{
${ }^{4}$ I would further argue that these perspectives should not only come from within academia but also from other sources of knowledge and cultural production.

${ }^{5}$ Chiseri-Strater (1996) argues that researchers are positioned by age, gender, 'race,' class, nationality, sexuality, institutional affiliation, intellectual predisposition, education history, and other aspects of their personal circumstances and experiences. This has direct implication for how inquiry is conducted and the data is interpreted.
} 
Chiseri-Strater, E. (1996). Turning in upon ourselves: Positionality, subjectivity and reflexivity in case study and ethnographic research. In P. Mortenson \& G. Kirsch (Eds.), Ethics and representation in qualitative studies (pp. 115-133). Urbana, IL: National Council of Teachers of English.

Conklin, J. (2005). Dialogue mapping: Building shared understanding of wicked problems. Hoboken, NJ: Wiley.

Countryman, M. (2020). 2020 uprisings, unprecedented in scope, join a long river of struggle in America. The Conversation, 7 June. https://theconversation.com/2020-uprisings-unprecedented-in-scope-join-a-longriver-of-struggle-in-america-139853. Accessed 23 June 2020.

Darder, A. (1992/2009). Epilogue: Teaching as an act of love: Reflections on Paulo Freire and his contributions to our lives and our work. In A. Darder, M. Baltonado, \& R. D. Torres (Eds.), The critical pedagogy reader (2nd ed., pp. 497-510). New York: Routledge.

Davis, A. (2018). Angela Davis on feminism, communism and being a Black Panther during the civil rights movement [Video File]. Channel 4 News, 25 May. https://youtu.be/x3q_qV5mHg0. Accessed 13 June 2020.

Escobar, A. (2007). Worlds and knowledges otherwise. Cultural Studies, 21(2), 179-210. https://doi. org/10.1080/09502380601162506.

Freire, P. (1973). Education: The practice of freedom. London: Writers and Readers Publishing Cooperative.

Friederich Ebert Stiftung (2020). Informal economy. http://www.fesghana.org/index.php?page=informaleconomy. Accessed 23 June 2020.

Functowicz, S., \& Pereira, A. G. (2015). Cartesian Dreams. In A. G. Pereira \& S. Functowicz (Eds.), Science, Philosophy and Sustainability: The end of the Cartesian dream(pp. 1-10). New York: Routledge.

Gangaji (2013). Who are you? [Video File]. 31 July. https://youtu.be/ybFmYNIk12U. Accessed 23 June 2020.

Ghana Health Service (2020). Updates on coronavirus disease (COVID-19) in Ghana as they happen. https://ghanahealthservice.org/covid19/. Accessed 19 June 2020.

Gordon, L. R. (2006). Disciplinary decadence: Living thought for trying times. Boulder, CO: Paradigm Publishers.

Grosfoguel, R. (2013). The structure of knowledge in westernized universities: Epistemic racism/sexism and the four genocides/epistemicides of the long $16^{\text {th }}$ century. Human Architecture: Journal of the Sociology of Self-Knowledge, 11(1), 73-90.

Haraway, D., Ishikawa, N., Scott, G., Olwig, K., Tsing, A., \& Bubandt, N. (2015). Anthropologists are talking - about the Anthropocene. Ethnos: Journal of Anthropology, 1-30. https://doi.org/10.1080 /00141844.2015.1105838.

Keating, A. (2013). Transformation now! Toward a post-oppositional politics of change. Urbana, IL: University of Illinois Press.

Knott, S. (2020). Ghana's decision to lift partial COVID-19 lockdown criticized by some. VOA News, 20 April. https://www.voanews.com/africa/ghanas-decision-lift-partial-covid-19-lockdown-criticized-some. Accessed 23 June 2020.

Latour, B. (2011). Networks, societies, spheres: Reflections of an Actor-Network theorist. International Journal of Communication, 5, 796-810.

Lock, M. (2015). Comprehending the body in the era of epigenome. Current Anthropology, 56(2), 151-177. https://doi.org/10.1086/680350.

Maparyan, L. (2012). The Womanist Idea. New York: Routledge.

Maron, D. F. (2020). 'Wet markets' likely launched the coronavirus. Here's what you need to know. National Geographic, 15 April. https:/www.nationalgeographic.com/animals/2020/04/coronavirus-linked-tochinese-wet-markets/. Accessed 23 June 2020.

Massey, D. (1991). A global sense of space. Marxism Today, June, 24-29. http://banmarchive.org. uk/collections/mt/pdf/91_06_24.pdf. Accessed 23 June 2020.

Massey, D. (1994). Space, place and gender. Cambridge, UK: Polity.

McLaren, P. (2001). Che Guevara, Paulo Freire, and the politics of hope: Reclaiming critical pedagogy. Cultural Studies $\leftrightarrow$ Critical Methodologies, 1(1), 108-131. https://doi.org/10.1177 /153270860100100112.

McLaren, P. (2007). Life in schools: An introduction to critical pedagogy in the foundations of education (5th ed.). New York: Pearson.

Mignolo, W. D. (2009). Epistemic disobedience, independent thought and de-colonial freedom. Theory, Culture \& Society, 26(7-8), 1-23. https://doi.org/10.1177/0263276409349275.

Miller, R. (2013). Changing the conditions of change by learning to use the future differently. In ISSC/UNESCO, World Social Science Report 2013: Changing Global Environments. OECD Publishing and UNESCO Publishing. https://doi.org/10.1787/9789264203419-en. 
Miller, R. (2015). Learning, the future, and complexity. An essay on the emergence of futures literacy. European Journal of Education, 50(4), 513-523. https://doi.org/10.1111/ejed.12157.

Mohamed, W. F. (2020) What COVID-19 reveals about educational inequality in Ghana. Al Jazeera, 7 April. https://www.aljazeera.com/indepth/features/covid-19-reveals-educational-inequality-ghana200407100729985.html. Accessed 23 June 2020.

Morrison, R. (2020). Now China says Wuhan wet market was NOT the origin of the coronavirus pandemic but it may have been the site of a 'super-spreader' event. Daily Mail, 29 May. https://www.dailymail.co. uk/sciencetech/article-8369085/Wuhan-wet-market-NOT-origin-coronavirus-pandemic.html. Accessed 23 June 2020.

Ndlovu-Gatsheni, S. J. (2015). Genealogies of coloniality and implications for Africa's development. Africa Development, $X L(3), 13-40$.

Osei-Boateng, C., \& Ampratwum, E. (2011). The informal sector in Ghana. Unpublished manuscript. Accra, Ghana: Friederich Ebert Stiftung.

Pearsall, P. (1999). The heart's code: Tapping the wisdom and power of our heart energy. Danvers, MA: Broadway Books.

Pearsall, P., Schwartz, G. E. R., \& Russek, L. G. S. (1999). Changes in heart transplant recipients that parallel the personalities of donors. Integrative Medicine, 2(2/3), 65-72. https://doi.org/10.1016/s1096-2190(00 00013-5.

Quartey, P. (2020). COVID-19 and the plight of private school teachers in Ghana. Accra, Ghana: Institute of Statistical, Social and Economic Research (ISSER). https://isser.ug.edu.gh/latest-news/covid-19-andplight-private-school-teachers-ghana. Accessed 23 June 2020.

Said, E. (1977/1995). Orientalism. In B. Ashcroft, G. Griffiths, \& H. Tiffin (Eds.), The post-colonial studies reader (pp. 87-91). London: Routledge.

Santos, B. (2014). Epistemologies of the South: Justice against epistemicide. London: Routledge.

Sardar, Z. (2010). Welcome to postnormal times. Futures, 42, 435-444. https://doi.org/10.1016/j. futures.2009.11.028.

Sardar, Z. (2015). Postnormal times revisited. Futures, 67, 26-39. https://doi.org/10.1016/j. futures.2015.02.003.

Sardar, Z., \& Sweeney, J. A. (2016). The three tomorrows of postnormal times. Futures, 75, 1-13. https://doi. org/10.1016/j.futures.2015.10.004.

Urry, J. (2007). Mobilities. Cambridge: Polity Press. 